\title{
КЛАСИФІКАЦІЯ НОРМА-ПАТОЛОГІЯ ПЕЧІНКИ ПО ФРАКТАЛЬНІЙ РОЗМІРНОСТІ БІНАРИЗОВАНОГО УЛЬТРАЗВУКОВОГО ЗОБРАЖЕННЯ
}

\author{
Кривошеєв Е.В., бакалавр \\ krivosheeverik@gmail.com \\ Настенко $\boldsymbol{C}$. А., к.т.н., д.б.н., ст.н.с. \\ nastenko.e@gmail.com \\ Павлов В.А., к.т.н.. доц. \\ pavlov.vladimir264@gmail.com \\ Кафедра біомедичної інженерії \\ Національний технічний університет України \\ «Київський політехнічний інститут імені Ігоря Сікорського» \\ м. Київ, Україна
}

\begin{abstract}
Реферат - обтрунтовано дочільність розробки алгоритму класифікачії на основі розрахунку фрактальної розмірності бінаризованого УЗ зображення печінки, запропоновано одержувати бінаризоване УЗ зображення з умови розрахунку порога бінаризачї̈, як значення відтінка сірого, частота присутності якого на зображенні найкращим чином розрізняє класи норми та патології.
\end{abstract}

Ключові слова - ультразвукове зображення, зона інтересу, бінаризаиія, фрактальна розмірність, метод k-найближчих сусідів, дерева рімень, точність, чутливість, специфічність.

\section{I. ВСТУП}

Приблизно кожна десята доросла людина у світі має проблеми з печінкою. Серед них: гепатоз, гепатит, цироз, рак та інші. Це тяжкі хвороби які потребують вчасного діагностування. Ультразвукове дослідження, на сьогодні, є найбільш популярним методом діагностики дифузних захворювань печінки. Та він має суттєвий недолік: точність постановки діагнозу, як правило, не перевищує 80\%. Для досягнення більшої точності використовують процедуру біопсії - інвазійний метод дослідження, при якому проводиться прижиттєвий забір тканин 3 організму. Цей метод $\epsilon$ травматичним та потребує періоду відновлення пацієнта. Метод може призводити до ускладнень, частота яких коливається від 1 до $20 \%$, та навіть до летальних наслідків у 0,1\%-2\%. Саме тому знаходження нових та покращення старих методів діагностики, які не потребують операційного втручання, $€$ актуальною темою для подальшого дослідження [1].

\section{II. МЕТА ДОСЛІДЖЕННЯ}

Метою даної роботи $\epsilon$ аналіз можливості застосування фрактальної розмірності бінаризованих УЗ зображень для використання у системах класифікації норма патологія при дифузних захворюваннях печінки.

Для досягнення мети в роботі формулюються та виконуються наступні завдання: аналіз УЗ зображень печінки в нормі та 3 патологією; визначення порогу та бінаризація зображень; знаходження фрактальної розмірності УЗ зображень; застосування алгоритму класифікації 3 використанням запропонованих ознак.

\section{III. ОПИС УЗ ЗОБРАЖЕНЬ}

Розглянемо принцип формування УЗ зображень. Датчик апарату УЗД випромінює ультразвук, яких поширюється в середовищах у вигляді зон стиснення $\mathrm{i}$ розширення речовини. Інтенсивність сигналу, яскравість та колір зображення залежить від величини акустичного опору тканин, що межують одна 3 одною: чим більша різниця між значеннями 
опору, тим більша інтенсивність зареєстрованого сигналу, тим світліше i яскравіше він буде виглядати на зображенні екрану.

При прогресі захворювання в результаті загибелі клітин печінки і розвитку на їх місці з'єднувальної тканини розміри печінки зменшуються, змінюється контур та поверхня. 3'являються нерівні, горбисті ділянки, які характеризують степінь фіброзу, чим вища стадія фіброзу, тим більші зони некрозу та більш виражені нерівності іiі контуру. У більшості хворих хронічним гепатитом нараховують до 23 ділянок неоднорідності на квадратний сантиметр [2]. На УЗ зображеннях це відображається скупченням світлих пікселів.

Для знаходження порогу бінаризації ультразвукових зображень було побудовано графік розподілення відтінків сірого в форматі RGB (вісь x - відтінок сірого в шкалі RGB, y частота відтінку) для усереднених гістограм зображень норми та патології отриманих на лінійному та конвексному датчиках[3].

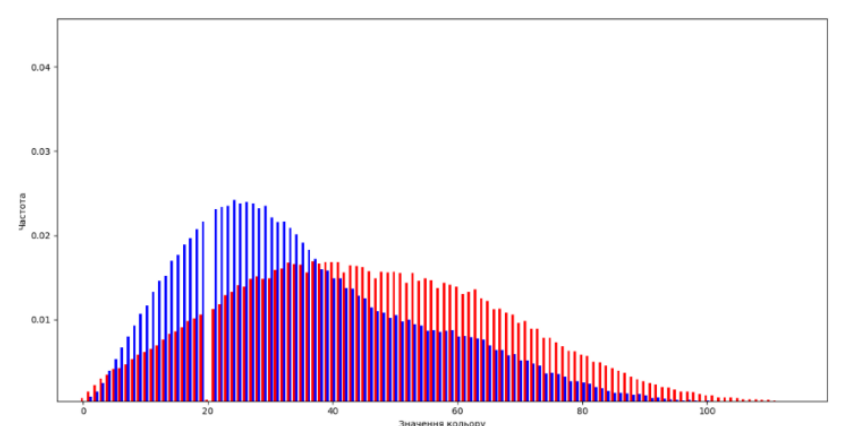

Рис. 1. Усереднені гістограми зображень 3 лінійного датчика.

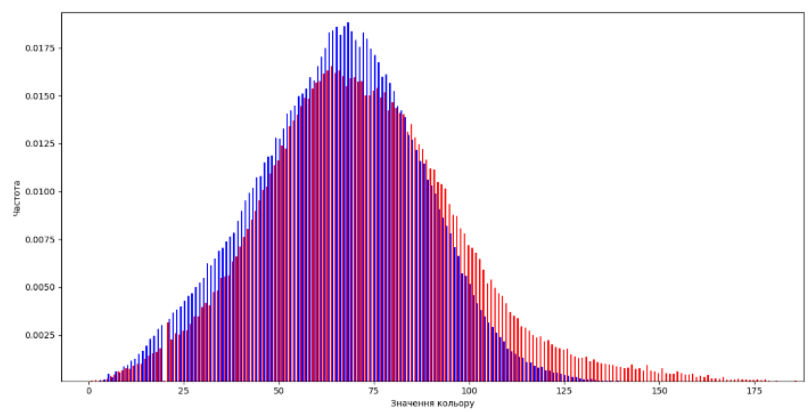

Рис. 2. Усереднені гістограми зображень 3 конвексного датчика.

Зображення 3 патологією, порівняно 3 нормою, мають статистично більше світлих ділянок та є більш неоднорідними. На графіках видно що для патології характерний зсув гістограми в вправо, в більш світлу гаму відтінків. Також треба відмітити що графіки зображень $з$ лінійного та конвексного датчиків суттєво відрізняються, 3 чого слідує що класифікацію зображень слід проводити роздільно.

\section{IV. БІНАРИЗАЦІЯ ЗОБРАЖЕННЯ}

Враховуючи наведені в попередньому пункті результати аналізу частотного розподілу кольорів було проведено бінаризацію. Поріг бінаризації було обрано роздільно для лінійного та конвексного датчика. Границя бінаризації - t, була обрана як значення відтінка сірого $з$ максимальною різницею за частотами норми та патології. Для лінійного датчика значення $\mathrm{t}=21$, для конвексного $\mathrm{t}=64$. Далі наведені приклади бінаризації зони інтересу ультразвукових зображення печінки для норми та патології отриманих на лінійному та конвексному датчику.
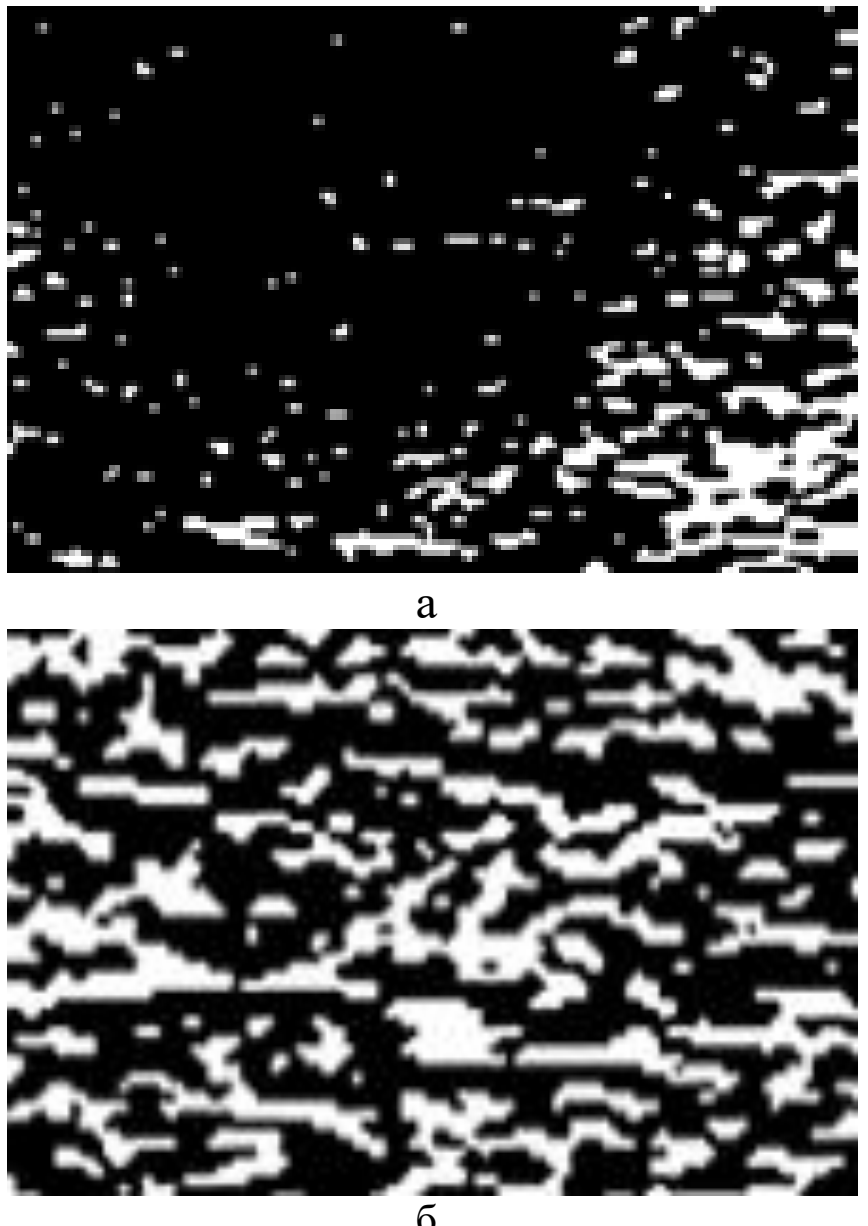

Рис. 3. Бінаризовані зображення норми та патології на лінійному датчику: а) норма; б) патологія. 

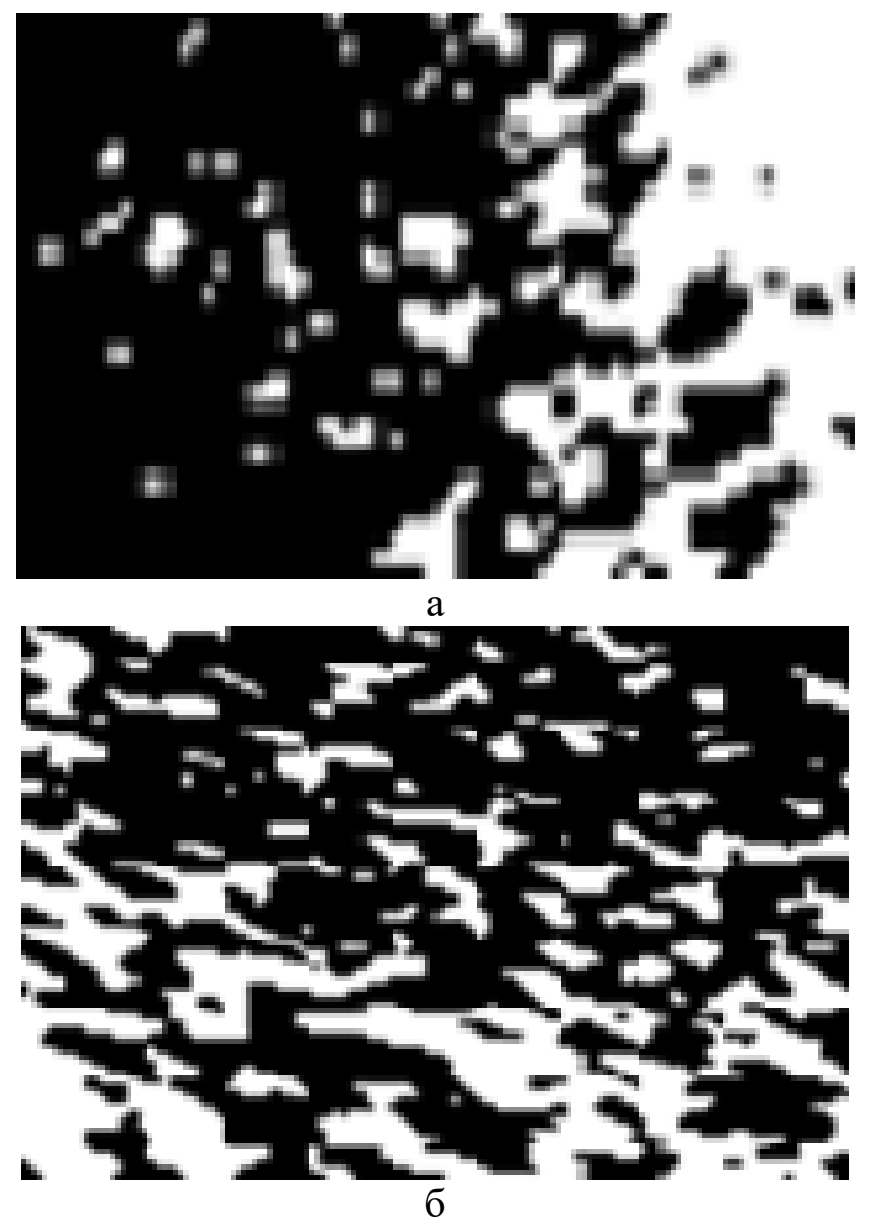

Рис. 4. Бінаризовані зображення норми та патології на конвексному датчику: а) норма; б) патологія.

На бінаризованих зображеннях для норми і патології присутня наочна відмінність, що може бути використано для підтримки прийняття рішення лікарем. Для норми характерні великі ділянки одного кольору, в той час як патологія характеризується неоднорідністю, частою зміною кольору, більш складним візерунком.

\section{V. ФРАКТАЛЬНА РОЗМІРНІСТЬ}

Для класифікації зображень пропонується розраховувати таку ознаку як фрактальна розмірність бінаризованого зображення. Фрактальна розмірність визначається як коефіцієнт, що відповідає мірі фрактальної структури або множини, що розраховується на основі кількісної оцінки їх складності [4]. Фрактальну розмірність Мінковського бінаризованих зображень норми та патології розраховано «box-counting» методом. Для цього попередньо було виділено контури чорних зон на бінаризованих зображеннях.
Нижче наведено гістограму частотного розподілу значень фрактальної розмірності УЗ зображень для норми та патології (вісь х значення, у - частота, синім кольором позначена норма, червоним - патологія).

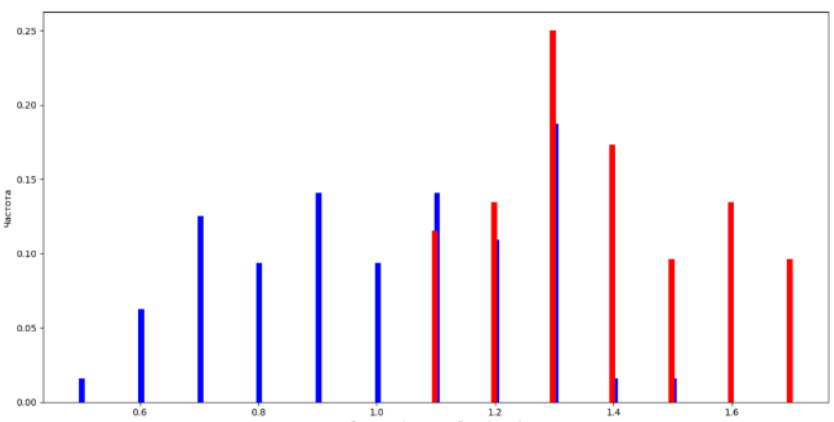

Рис. 5. Частота розподілу значень фрактальної розмірності для лінійного датчика.

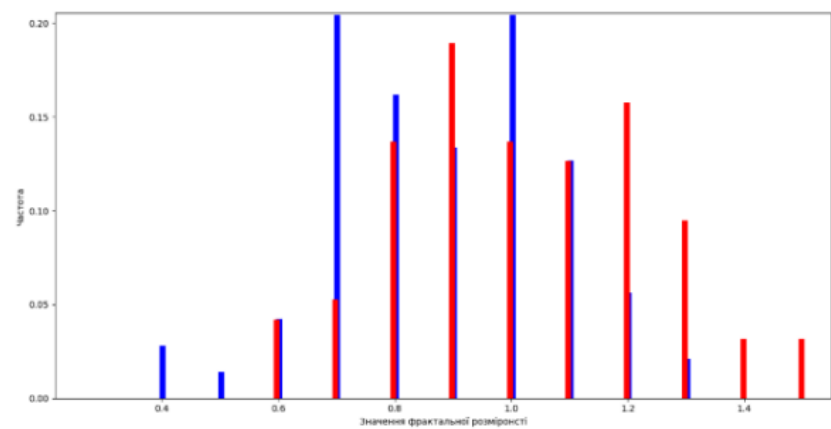

Рис. 6. Частота розподілу значень фрактальної розмірності для конвексного датчика.

Було встановлено середні мінімальні та максимальні значення фрактальної розмірності бінаризованих зображень норми та патології отриманих на лінійному та конвексному датчиках.

Розглянемо результати для лінійного датчика і порівняємо значення фрактальної розмірності та відповідні їм бінаризовані зображення.

Таблиия 1

Значення фрактальної розмірності на лінійному датчику

\begin{tabular}{|l|l|l|l|}
\hline \multicolumn{1}{|c|}{ Клас } & Мінімальне & Середнє & Максимальне \\
\hline Норма & 0.57 & 0.997 & 1.47 \\
\hline Патології & 0.92 & 1.370 & 1.748 \\
\hline
\end{tabular}

Наведемо приклад градації бінаризованих зображень за значенням фрактальної розмірності в послідовності: типічна норма, пограничне значення норми, типічна патологія. 


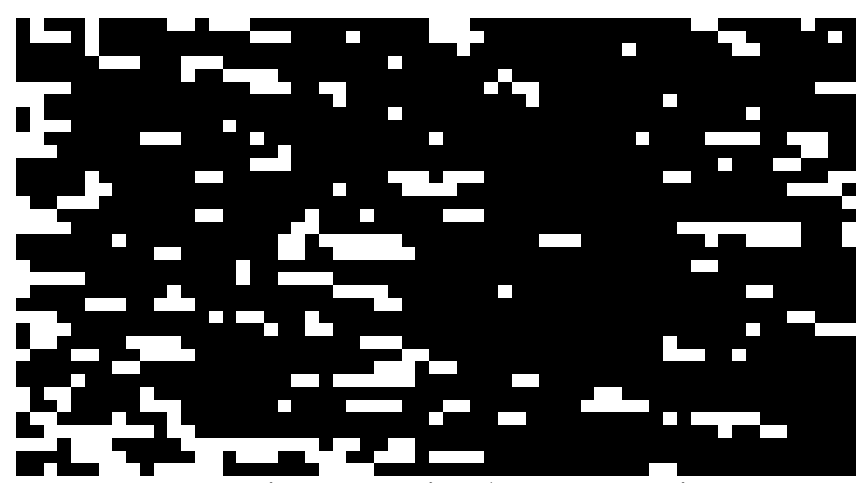

Рис. 7. Бінаризовані зображення типічної норми з лінійного датчика, значення фрактальної розмірності 0.9 .

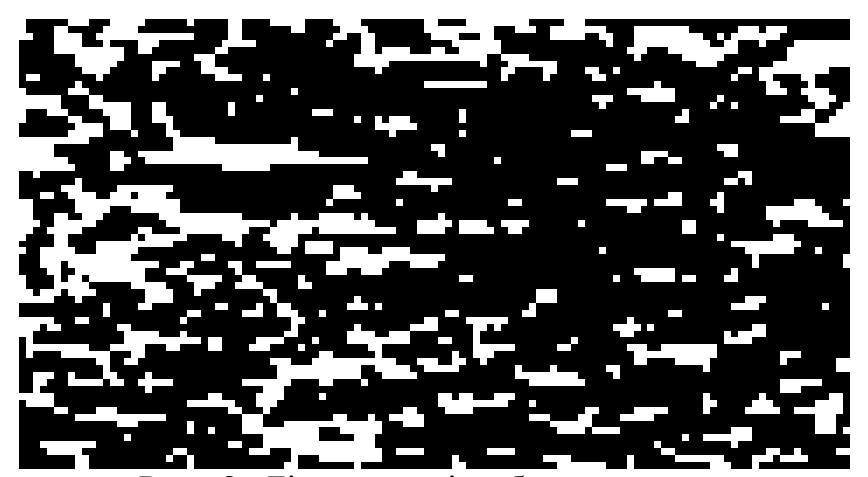

Рис. 8. Бінаризовані зображення пограничної норми 3 лінійного датчика, значення фрактальної розмірності - 1.16 .

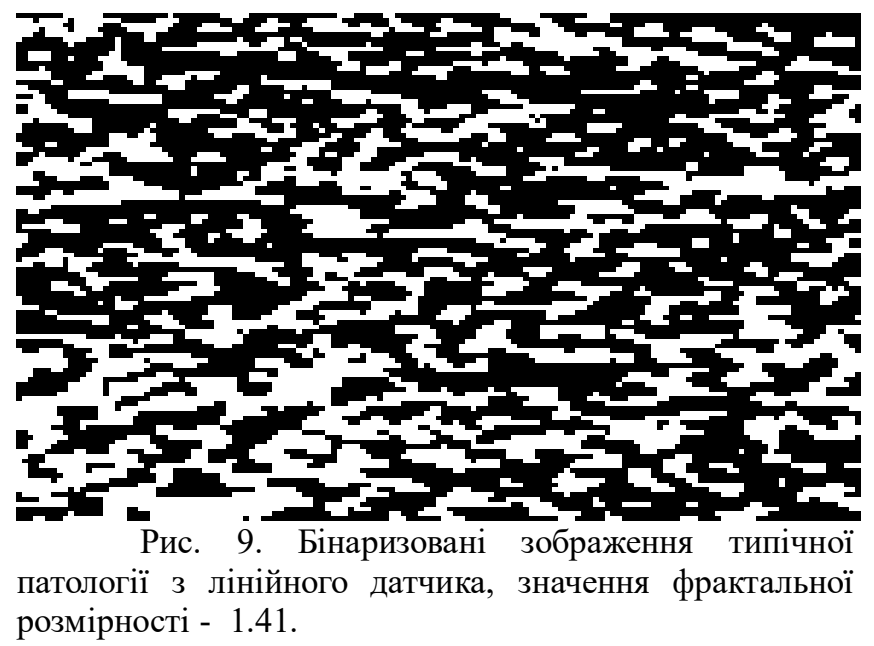

Знизу наведено значення фрактальної розмірності та градація зображень для результатів отриманих з конвексного датчика.

Таблиия 2

Значення фрактальної розмірності на

\begin{tabular}{|l|l|l|l|}
\hline \multicolumn{4}{c|}{ конвексному датчику } \\
\hline Клас & Мінімальне & Середнє & Максимальне \\
\hline Норма & 0.32 & 0.77 & 1.25 \\
\hline Патології & 0.57 & 0.94 & 1.4 \\
\hline
\end{tabular}

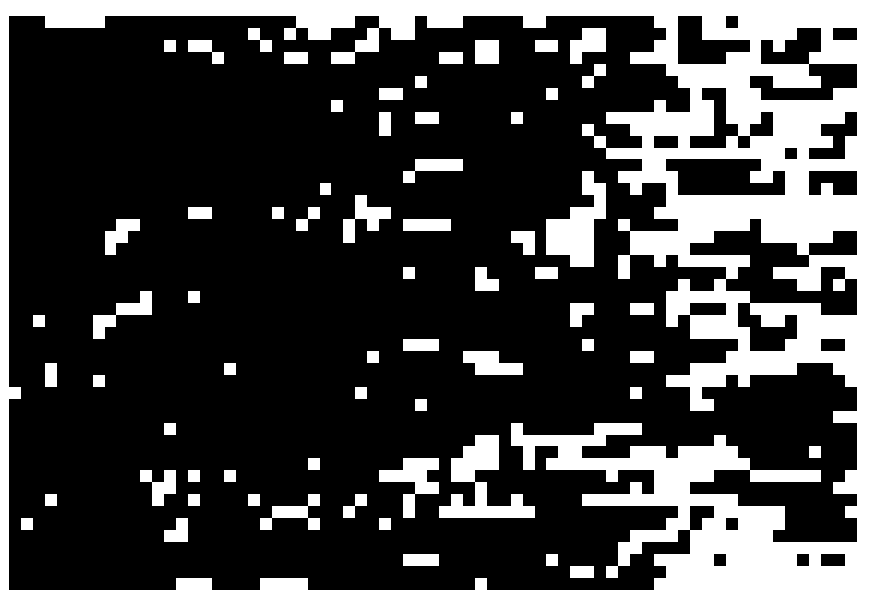

Рис. 10. Бінаризовані зображення типічної норми 3 конвексного датчика, значення фрактальної розмірності - 0.7 .

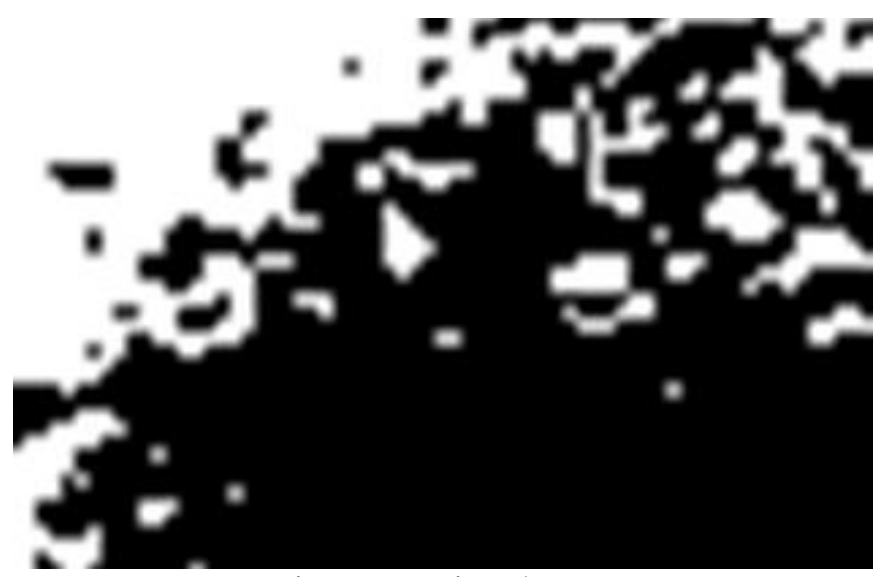

Рис. 11. Бінаризовані зображення пограничної норми 3 конвексного датчика, значення фрактальної розмірності - 0.95 .

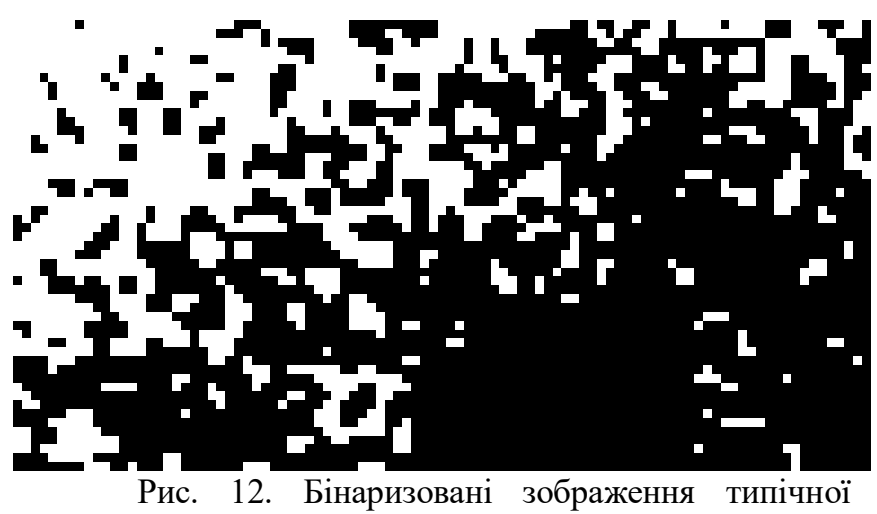
патології з конвексного датчика, значення фрактальної розмірності - 1.32 .

Граничні значення норми і патології для лінійного датчика відрізняються більше ніж для конвексного, крайні значення для норми лінійного та патології для конвексного датчика збігаються. Дані факти дозволяють ствердити, що навчання класифікатора даною ознакою по збірній вибірці лінійного та конвексного датчику буде неефективним. Результати порівняння значення фрактальної розмірності 
та бінаризованих зображень підтверджують їх зв'язок.

\section{VI. КЛАСИФІКАЦІЯ}

Розглянемо застосування фрактальної розмірності бінаризованого УЗ зображення для класифікації норма-патологія печінки методом k-найближчих сусідів [5] та за допомогою дерева рішень [6]. Два метода класифікації було обрано для порівняння їх ефективності на наявних вхідних даних.

Таблиия 3

Опис вхідних даних

\begin{tabular}{|l|l|l|}
\hline \multicolumn{1}{|c|}{ Тип датчика } & \multicolumn{1}{|c|}{ Клас } & \multicolumn{1}{c|}{ Кількість } \\
\hline \multirow{2}{*}{ Лінійний } & Норма & 72 \\
\cline { 2 - 3 } & Патологія & 55 \\
\hline \multirow{2}{*}{ Конвексний } & Норма & 158 \\
\cline { 2 - 3 } & Патологія & 107 \\
\hline
\end{tabular}

Тестування проводиться окремо на кожному з датчиків. Розбиття на навчальну та тестову вибірки (80\%-20\%) застосовано двома методами: 1) кросс-валідація; 2) рівномірне розбиття за внутрішньогруповою дисперсією.

Для застосування фрактальної розмірності при класифікації УЗ зображень в ансамблі ознак додатково було обрано статистичні показників текстури ультразвукових зображень, що запропоновані у [7] :

1. x1_orig - діапазон стабільності значень в області низьких інтенсивностей комбінацій відтінків сірого.

2. x2_orig - величина найкращого дискримінуючого (патологія-норма) значення частоти комбінацій відтінків сірого сусідніх пікселів.

3. x3_orig - величина найбільшого значення на шкалі відтінків сірого, частота якого (с точністю до рівня значущості) присутня на гістограмі матриці суміжності.

Вказані ознаки були обрані як ті, що найкраще розріняють норму та патологію печінки серед інших відомих ознак текстури [7].

Далі наведено результати тестування для різних наборів ознак за допомогою методу k-найближчих сусідів.
Табличя 4

Результати тестування класифікації на основі розмірності Мінковського

\begin{tabular}{|c|c|c|c|c|}
\hline \multirow{2}{*}{ Датчик } & \multirow{2}{*}{ Значення } & \multirow{2}{*}{$\begin{array}{l}\text { Кросс- } \\
\text { валід. }\end{array}$} & \multicolumn{2}{|c|}{$\begin{array}{c}\text { За внутрегруповою } \\
\text { дисперсією }\end{array}$} \\
\hline & & & $\begin{array}{c}\text { Екзам. } \\
\text { данні }\end{array}$ & $\begin{array}{c}\text { Навч. } \\
\text { вибірка }\end{array}$ \\
\hline \multirow{3}{*}{ Лінійний } & Точність & 0.76 & 0.63 & 0.88 \\
\hline & Чутливість & 0.72 & 0.62 & 0.85 \\
\hline & Специф. & 0.79 & 0.64 & 0.9 \\
\hline \multirow{3}{*}{ Конвекс. } & Точність & 0.61 & 0.59 & 0.79 \\
\hline & Чутливість & 0.42 & 0.5 & 0.73 \\
\hline & Специф. & 0.7 & 0.66 & 0.83 \\
\hline
\end{tabular}

Проведемо тестування на ознаках статистичних показників текстури ультразвукових зображень.

Таблиия 5

Результати тестування класифікації на основі вибраних ознак текстури печінки

\begin{tabular}{|c|c|c|c|c|}
\hline \multirow{2}{*}{ Датчик } & \multirow{2}{*}{ Значення } & \multirow{2}{*}{$\begin{array}{l}\text { Кросс- } \\
\text { валід. }\end{array}$} & \multicolumn{2}{|c|}{$\begin{array}{c}\text { За внутрегруповою } \\
\text { дисперсією }\end{array}$} \\
\hline & & & $\begin{array}{r}\text { Екзам. } \\
\text { данні }\end{array}$ & $\begin{array}{c}\text { Навч. } \\
\text { вибірка }\end{array}$ \\
\hline \multirow{3}{*}{ Лінійний } & Точність & 0.67 & 0.58 & 0.81 \\
\hline & Чутливість & 0.63 & 0.45 & 0.76 \\
\hline & Специф. & 0.7 & 0.69 & 0.85 \\
\hline \multirow{3}{*}{ Конвекс. } & Точність & 0.63 & 0.63 & 0.8 \\
\hline & Чутливість & 0.44 & 0.45 & 0.66 \\
\hline & Специф. & 0.77 & 0.75 & 0.89 \\
\hline
\end{tabular}

Таблиия 6

Результати тестування класифікації на об'єднаному ансамблі ознак

\begin{tabular}{|c|c|c|c|c|}
\hline \multirow{2}{*}{ Датчик } & \multirow{2}{*}{ Значення } & \multirow{2}{*}{$\begin{array}{l}\text { Кросс- } \\
\text { валід. }\end{array}$} & \multicolumn{2}{|c|}{$\begin{array}{c}\text { За внутрегруповою } \\
\text { дисперсією }\end{array}$} \\
\hline & & & $\begin{array}{r}\text { Екзам. } \\
\text { данні }\end{array}$ & $\begin{array}{c}\text { Навч. } \\
\text { вибірка }\end{array}$ \\
\hline \multirow{3}{*}{ Лінійний } & Точність & 0.86 & 0.88 & 0.92 \\
\hline & Чутливість & 0.82 & 0.91 & 0.88 \\
\hline & Специф. & 0.9 & 0.85 & 0.95 \\
\hline \multirow{3}{*}{ Конвекс. } & Точність & 0.65 & 0.64 & 0.83 \\
\hline & Чутливість & 0.48 & 0.6 & 0.73 \\
\hline & Специф. & 0.78 & 0.75 & 0.91 \\
\hline
\end{tabular}


Для порівняння значення точності класифікації за допомогою дерева рішень наведено низче.

Таблиця 7

Результати тестування класифікації по ознаках текстури

\begin{tabular}{|c|c|c|c|c|}
\hline \multirow[b]{2}{*}{ Датчик } & \multirow[b]{2}{*}{ Значення } & \multirow{2}{*}{$\begin{array}{c}\text { Кросс- } \\
\text { валід. }\end{array}$} & \multicolumn{2}{|c|}{$\begin{array}{c}\text { За внутрегруповою } \\
\text { дисперсією }\end{array}$} \\
\hline & & & $\begin{array}{l}\text { Екзамен. } \\
\text { вибірка }\end{array}$ & $\begin{array}{l}\text { Навч. } \\
\text { вибірка }\end{array}$ \\
\hline \multirow{3}{*}{ Лінійний } & Точність & 0.61 & 0.51 & 0.52 \\
\hline & Чутливість & 0.5 & 0.46 & 0.2 \\
\hline & Специф. & 0.72 & 0.55 & 0.82 \\
\hline \multirow{3}{*}{ Конвекс. } & Точність & 0.55 & 0.54 & 0.59 \\
\hline & Чутливість & 0.7 & 0.47 & 0.55 \\
\hline & Специф. & 0.44 & 0.64 & 0.65 \\
\hline
\end{tabular}

Таблиия 8

Результати тестування класифікації на всіх

\begin{tabular}{|c|c|c|c|c|}
\hline \multicolumn{5}{|c|}{ ознаках } \\
\hline \multirow[b]{2}{*}{ Датчик } & \multirow[b]{2}{*}{ Значення } & \multirow{2}{*}{$\begin{array}{l}\text { Кросс- } \\
\text { валід. }\end{array}$} & \multicolumn{2}{|c|}{$\begin{array}{c}\text { За внутрегруповою } \\
\text { дисперсією }\end{array}$} \\
\hline & & & $\begin{array}{c}\text { Екзамен. } \\
\text { вибірка }\end{array}$ & $\begin{array}{l}\text { Навч. } \\
\text { вибірка }\end{array}$ \\
\hline \multirow{3}{*}{ Лінійний } & Точність & 0.87 & 0.75 & 0.81 \\
\hline & Чутливість & 0.8 & 1 & 0.65 \\
\hline & Специф. & 1 & 0.62 & 1 \\
\hline \multirow{3}{*}{ Конвекс. } & Точність & 0.57 & 0.64 & 0.6 \\
\hline & Чутливість & 0.43 & 0.67 & 0.87 \\
\hline & Специф. & 0.79 & 0.62 & 0.2 \\
\hline
\end{tabular}

Результати класифікації нормапатологія печінки по фрактальної розмірності бінаризованого УЗ зображення методом kнайближчих сусідів та за допомогою дерева рішень, дозволяють стверджувати ефективність та доцільність використання фрактальної розмірності для класифікації патологій у ансамблі з обраними ознаками текстури зображення. Було встановлено, що на запропонованому наборі вхідних ознак класифікації методом k-найближчих сусідів $\epsilon$ більш ефективною.

\section{VII. ЗАКЛЮЧЕННЯ}

1. Частотні характеристики відтінків сірого УЗ зображень печінки для лінійного датчика суттєво відрізняються для норми та патології. Для патології печінки характерний зсув гістограми в вправо, в більш світлу гаму відтінків.

2. Значення відтінка сірого, частота присутності якого на УЗ зображенні найкраще розрізняє норму та патологію печінки доцільно використати для бінаизації зображень.

3. Бінаризовані зображення можуть бути використанні як образні індикатори для підтримки прийняття лікарем діагностичного висновку.

4. Фрактальна розмірність бінаризованого зображення $\epsilon$ ефективною ознакою при класифікації УЗ зображень печінки.

5. Метод класифікації k-найближчих сусідів у просторі ансамблю вибраних ознак текстури та фрактальної розмірності бінаризованих зображень дозволяє досягти високих показників якості класифікації, як на навчальній, так і на тестовій вибірці пацієнтів.

\section{ПЕРЕЛІК ПОСИЛАНЬ}

[1] Болезни печени / [С.Д. Подимова]. // Медицинское Информационное Агенство Москва, 2018 - 967 с.

[2] Ультразвукова диагностика. / [Едвард Блют]. // Медицинская литература, Плєшков Ф. І., 2014 - 192 с.

[3] Практична статистика для фахівців Data Science. / [Ендрю Брюс, Пітер Брюс]. // БХВ-Петербург, 2017 - 304 с.

[4] Fractals in Biology and Medicine / [Mantegna R. N., Havlin S., Buldyrev S.V.]. // Department of Biology, MIT, 1995 - 201 p.

[5] Загальна теорія статистики. / [Ткач Є., Сторожук В.]. // Центр навчальної літератури, 2017 - 442 с.

[6] Фрактальные размерности для времен возвращения Пуанкаре/ [Афраймович В., Угальде Э., Уриас Х.] // Удмуртский университет, 2011 - 292 с.

[7] Класифікація станів печінки при дифузних захворюваннях на основі статистичних показників текстури ультразвукових зображень та МГУА. Індуктивне моделювання складних систем. / [Є.А.Настенко., I.М. Дикан, Б.А. Тарасюк, В.А. Павлов, О.К. Носовець, В. О. Бабенко, В.В. Круглий, М.Б.Диба, В.В. Солодущенко]. // Збірник наук. праць. К.: МННЦІТС, Вип.11, 2019- 104-113 С. 


\title{
КЛАССИФИКАЦИЯ НОРМА-ПАТОЛОГИЯ ПЕЧЕНИ ПО ФРАКТАЛЬНОЙ РОЗМЕРНОСТИ БИНАРИЗИРОВАНОГО УЛЬТРАЗВУКОВОГО ИЗОБРАЖЕНИЯ
}

\author{
Кривошеев Э.В., бакалавр \\ krivosheeverik@gmail.com \\ Настенко Е. А., к.т.н., д.б.н., ст.н.с. \\ nastenko.e@gmail.com \\ Павлов В.А., к.т.н.. доц. \\ pavlov.vladimir264@gmail.com \\ Кафедра биомедицинской инженерии \\ г. Киев, Украина
}

Национальный технический университет Украины

«Киевский политехнический институт имени Игоря Сикорского»

Реферат - обоснована цеелесообразность разработки алгоритма классификации на основе расчета фрактальной размерности бинаризированых УЗ изображений печени, предложено получать бинаризированые УЗ изображения из условия расчета порога бинаризации, как значение оттенка серого, частота присутствия которого на изображении лучшим образом различает классы нормы и патологии.

Ключевые слова - ультразвуковое изображение, зона интереса, бинаризация, фрактальная размерность, метод k-ближайших соседей, деревья решений, точность, чувствительность

UDC 616.1-616.7

\section{CLASSIFICATION OF NORMAL- PATHOLOGY OF LIVER BY FRACTAL DIMENSION OF BINARIZED ULTRASOUND IMAGE}

\author{
Krivosheiev E.V., bachelor \\ krivosheeverik@gmail.com \\ Nastenko Ie.A., Ph.D., Doctor of Biological Sciences, \\ Senior researcher \\ nastenko.e@gmail.com \\ Pavlov V.A., Ph.D., doc. \\ pavlov.vladimir264@gmail.com \\ Department of Biomedical Engineering \\ National Technical University of Ukraine \\ "Igor Sikorsky Kyiv Polytechnic Institute"
}

Kiev, Ukraine

\footnotetext{
Abstract - the expediency of developing a classification algorithm based on calculating the fractal dimension of a binary ultrasound image of the liver is substantiated, it is proposed to obtain a binarized ultrasound image from the calculation of the binarization threshold as the value of gray, the frequency of which in the image best distinguishes classes of norm and pathology.
}

Keywords - ultrasound image, area of interest, binarization, fractal dimension, $k$-nearest neighbors method, decision trees, accuracy, sensitivity, specificity. 